\title{
INTERNATIONAL COMMODITY TRADE: A SCHEME FOR EXPORT EARNINGS ENTITLEMENTS
}

By Leelananda De Silva

\section{The Approach So Far}

The correction of trends adverse to developing countries in the international trade in commodities constitutes a primary focus of New International Economic Order (NIEO) negotiations. Negotiations on these issues preceded the enunciation of the principles of an NIEO and could be traced back to well over half a century when incipient North-South debates were held to resolve outstanding issues. The commodity question can also be credited with the initial impetus for concrete expression of the concept of Collective Self Reliance among developing countries through the formation of Producer Associations. In spite of the long history of involvement of both international organizations and their member countries to resolve the major issues in the trade in primary commodities, the results achieved so far, though not insignificant, fall short of the objectives set by the developing countries. The conclusion of the negotiations on the Common Fund is a significant milestone in the history of the international trade in primary commodities and the Second Window of the Fund provides, more specifically, further avenues for the advancement of Third World causes.

The negotiations relating to commodity issues at an inter-governmental level are broadly in two stages. First, commodity-producing countries attempt to concert their positions taking account of their distinctive and sometimes divergent interests and a common strategy for negotiations with consuming countries is evolved. The negotiations with consumer countries is the next step in the inter-governmental process and the success or failure of negotiations depends primarily on the depth and the degree to which producer countries have effected a common strategy among themselves. It has been the experience in most commodities that substantial differences exist among producing countries which are not suitably reconciled at the stage of the negotiations with consuming countries that it has been possible for the latter to drive hard bargains and conclude international commodity agreements or sometimes more informal understandings, which provide only very marginal gains to developing countries.

A series of techniques which form the stock ingredients of commodity agreements have emerged over the years and are now common features of any agreement involving either producers or producers and consumers. Buffer stocks, export quotas (and sometimes export levies) and production controls are the primary techniques, supported by measures for diversification, long-term contracts, and access to markets both for raw and processed products. The Integrated Programme for Commodities incorporates not only these techniques but goes beyond them, not only in finding solutions to issues on the basis of an integrated commodity approach, but by introducing new elements in the form of Compensatory Financing and Indexation. The IMF and the Lome Convention already operate schemes for compensatory financing though not in the context of any international commodity agreements. It might even be that such schemes deter developing countries from effective forms of producer co-operation. As for indexation, there is yet not international agreement though OPEC appears to have achieved the same objectives unilaterally and the industrialized countries are certainly in the mood to accept future pricing formulae for oil on that basis. Broadly, two kinds of solutions are currently considered at an international level to over- 
come the problems which confront international trade in commodities. One is the international commodity agreement based on the type of technique referred to above where a degree of producer co-operation is essential. Secondly, in view of the failure to reach the desirable levels of producer co-operation, compensatory financing and indexation are deemed appropriate. The IMF and organizations like the OECD and EEC prefer compensatory financing mechanisms which interfere least with present patterns of international trade while institutions like UNCTAD and the Group of 77 are more in favour of international commodity agreements and indexation, though compensatory financing is considered a useful mechanism, at least in the short run. It is, however, the failure to regulate supplies through producer co-operation that makes imperative international action on commodities on the basis of compensatory financing schemes. It might be noted at this stage that an international consensus is implicitly being evolved which recognizes total commodity earnings either for a country or for a commodity as the central issue to be resolved if the required level of resources are to be assured for developing countries.

\section{Export Earnings Entitlements - The Scheme}

It is the contention of this paper that the techniques and measures sought to be adopted within the framework of international commodity agreements are a fundamental cause of the failure of commodity-producing countries to act in collusion to regulate supplies for export. Export quotas and production controls, and to a lesser extent, buffer stocks demand from these countries substantial costs and sacrifices without commensurate benefits in the short run. These techniques fail to bring about a convergence between what is good and beneficial for the group of commodity-producing countries as a whole and the interests of each of its constituent parts. Though everyone seems to agree on the need for global quotas, the allocation of shares raises insuperable obstacles thus nullifying the objective of establishing a tight global quota for a commodity. These developments are essentially the consequence of the present system of treating each country's export earnings from a commodity as an independent variable even when a global quota is established. The earnings of each country are dependent on the volume it exports and so long as this relationship persists, each country would clamour to obtain the highest possible share of the global quota. The need for a limited global quota on the one hand, and the demand of each producing country for the maximum possible share on the other constitute conflicting trends which result ultimately in reducing the level of global earnings for that commodity.

To overcome these obstacles and conflicts, it is proposed that the relationship between export volumes and export earnings for each individual producing/exporting country be delinked and that these two elements be considered as serving two distinct functions in the context of international commodity agreements. The function of theglobal export volume quota is to obtain the maximum global export earnings for the producing/exporting countries. The interest of each country lies in obtaining the highest allocation possible from global export earnings. Each country contributes to the achievement of a high level of global export earnings in two ways - by exporting a defined quantity of the commodity in consonance with the global export quota and by withholding exports of a certain quantity to enable the global quota to be kept within its defined limit. So far.countries are obliged to export the maximum quantity as export revenues are dependent on export volume levels. But once this relationship is broken, and export earnings allocated for the contribution each country makes for the 
maximization of total export earnings, either through exports, or withholding exports, then no country would necessarily opt to obtain the maximum possible volume quotas.

A basic conflict of interests in the allocation of quotas, within international commodity agreements, is between the old, traditional producers whose levels of production and exports are stabilized or even declining, and the new producers/exporters who are entering an expansionary phase in their production programmes. The latter are also inclined to be low-cost producers. Reconciliation of these divergent interests within a tight global quota has been virtually impossible using present techniques of supply management. If export earnings are de-linked from export volumes, it is demonstrably feasible to allow new producers larger export volume quotas and the old producers might be satisfied with lower quota levels. However, even if that is not possible, the level of earnings could be so adjusted to make increased exports and production less attractive than it is now.

The de-linking of export earnings from export volumes does not mean that export volumes are not important for share allocation. It will still be a factor of considerable weight. However, it should be seen in the perspective of the imperatives of export earnings maximization. The major emphasis given to export volumes as central to export earnings is fundamental to the present problems of supply management and the Export Earnings Enitlement Scheme is a device to move away from this pattern of thinking.

Three features are central to the operation of an Export Earnings Entitlements Scheme, though several other issues of an subsidiary nature must be negotiated for its sustained efficiency.

(1) The determination of the desirable level of global export earnings from the commodity. The unit price expected to be achieved, and the level of supplies to be ensured are the most important factors in this determination.

(2) The allocation of the total export earnings among producing/exporting countries.

(3) The allocation of export volume quotas among exporting countries.

\section{Global Level of Export Earnings}

A major element of the Export Earnings Entitlement Scheme (EEES) is the total earnings from a commodity which accrue to all countries producing that commodity. If only developing country producers are concerned, the relevant figure will be the total earnings of this group of countries. Initially the commodity producing countries will be concerned with the total size of the earnings which accrue to them by the export of the commodity concerned and their relative shares in that total. It is consistent with the interest of all producer countries to agree on a figure of total earnings for an individual commodity sustainable in the long run and, if necessary, substantially increased.

To arrive at an optimal figure for the size of total earnings (not necessarily actual figures on any previous date), several factors must be considered. Price elasticities of demand, the possibility of entry of new competitors, the potential for substitution and other such factors are deemed relevant. The size of total earnings will be equal to the price per unit into the number of units exported, assuming homogeneity of the product. This is an assumption which can be suitably modified to take note of any variations in product quality. Producer countries desire to maximize their export earnings and would therefore have to agree on exporting globally only a certain quantity. Restrictions will have to be imposed on the level of exports. However, the scheme would differ from any previous proposals in that the share of export earnings accruing to a country would not necessarily depend on the volume of its exports. 
At the stage of producer country co-operation to determine a desirable level of total export earnings from the commodity, the issues for discussion will be the level at which global exports should be fixed to obtain the desirable price per unit to obtain the size total of export earnings considered both feasible and desirable. If commodity prices have declined in real terms due to an excess in supplies, then supply curtailment is of the essence. The extent to which supply should be curtailed to obtain maximum total export revenues is a matter for negotiation. However, there cannot be a conflict of interests among producing countries at this stage. It is possible at this stage to devise a figure for total earnings from year to year which maintains the price per unit in real terms based on either a desirable previous price or a notional price taking into account factors which include costs of production and what the market would bear.

\section{Allocation of Export Earnings Entitlements (EEES)}

This will be the area of hard bargaining. In previous schemes it used to be the export volume quota. The only, and most vital, difference now will be that cash is liquid, flexible and stockable and it is cash that is being allocated. The negotiations will be eased to the extent that compensation means a shift of cash not a quantity of commodities. Export earnings will be allocated to each country on the basis of criteria to be negotiated. The higher the total export earnings, the higher will be each country's share. The substantial costs of failure to reach agreement should assist in the determination of a successful outcome. While there was a common interests in the total size of export earnings, there will be no convergence of interests in share allocations. Each country would claim the maximum share for itself. It is the task of an agreement to set out clearly the formulae for share allocation. The formulae could be determined by the following criteria, among others:

(1) The share of total export earnings in previous years. This share might have varied but the reasons for such variation could be analyzed. Standard variations in the quality of the product would be evident in these figures.

(2) The potential level of exports in the current year and the corresponding national share of total global exports if there were no agreement and no supply restriction.

If the product is homogeneous and allowing for transport costs, the unit prices would be more or less the same for each country and in that situation the share of exports in volume terms should bear a close correlation to exports in value terms.

(3) New and expanding producers to be given an increasing share within limits, and traditional and high-cost producers to take a declining share, within limits, in the share allocation of export earnings.

The potential for exports both in the short and in the longer run will be a stong criterion in the allocation of shares, and a primary reason for de-linking export volumes from export earnings. Countries should be encouraged to curtail production by reasonably generous incentives in the form of a higher share of export earnings. Initially this might mean only curbs in production but not in the capacity for production. If the agreement is viable in the long run, it would encompass the latter. It is also feasible to evolve formalae which consists of a two-tiered system of earnings allocations. The first tier will hold up to a certain total of export earnings and above that figure, the allocations could be on other criteria. 


\section{Export Volume Quotas}

The third element is to allocate to each producer country an export volume quota consistent with the maintenance of the global export figure determined previously. It must be noted that, irrespective of the quantities exported, the share of total export earnings is determined. Once the link between the volume exported and the earnings accrued is snapped, it is perfectly feasible to allocate export volume quotas without any serious haggle. In fact, if anything, exporting countries will have an inducement to export less, particularly in the case of countries which have a domestic absorptive capacity for the commodity concerned. By exporting and therefore producing less in the case of certain commodities, major economies in resource use might be effected. In this context what would be necessary is not a maximum export quota but a minimum export quota - a quota which each country is obliged to supply the world market. In assigning quotas, it should be possible to fix quotas at the full exportable level in the case of new producing countries in a stage of expanding production and also for those countries with a limited domestic absorptive capacity, and fix quotas below the full exportable level for the old high-cost producers and those with a large domestic market. There will be no incentive for any individual producer to export more than their quota as earnings will not increase by such action.

The objective at this stage would be to reconcile two hitherto conflicting strands in producer co-operation - to maximize global export revenues while allowing for a degree of structural change in production capacity. The measures proposed overcome the obstacles associated with the usual export quota and production control measures.

A major assumption of the proposal is that export restrictions of a suitable magnitude would increase total export earnings substantially beyond what they would otherwise be if there were no intervention on the level of exports. Given the elasticity of demand for most primary commodities, this is not an unreasonable assumption to make. Given also the possibility of incremental revenues and assuaged of the fears which normally arise for some producers in the matter of export quotas and production controls, there will be every incentive for all producers to negotiate a producers agreement to formulate and implement an Export Earnings Entitlement Scheme.

The description attempted above raises several questions regarding the feasibility of continuing with such a scheme for all producers. It is an essential part of the scheme at least in its initial stage not to interfere with any production expansion programmes. However, it is in the very nature of the scheme that producer countries will realize that they obtain the benefits of higher export revenues without necessarily obtaining a corresponding increase in export volumes. At least in relation to agricultural commodities like tea, rubber, cocoa, coffee and sugar, where the opportunity cost of land is substantially high, there will be a major incentive to switch to non-export food crops. It is possible to visualize such a dimension as part of a producer agreement - a Diversification Fund, financed by the increased revenues accruing from a tight market situation. The incremental revenue arising from producer co-operation could be substantial, if prices are sustained in real terms and even improved upon in some cases.

The discrepancy that would emerge between export volumes and export earnings reflects the difference in the unit values for the commodity which accrue to different producing/exporting countries under the scheme. Some countries will obtain higher unit values and others less, but broadly it would be the "high cost" old producers in the former category, and the "low cost" new producers in the latter. There is also a further factor which might create distortions. That is the incremental gain in welfare accruing to those countries with a large 
domestic market which will now have increased supplies available. These factors will not necessarily be of great advantage, or of any significant cost, during the earlier stages of an agreement as those producers obtaining higher export volume quotas will do so of their own volition and to their own advantage. However, at a subsequent time these features might constitute distortions which have to be corrected by the necessary compensatory payments.

\section{An Outline with Numbers}

It is possible to note at this stage two hypothetical situations wherein prices increase by 25 per cent and 50 per cent, following the withdrawal of 15 per cent of export supplies of a commodity - in a total market of 1 million tons. If the unit value is $\$ 2$ a kilo or $\$ 2000$ a ton, the total accruals to exporters will increase from $\$ 2$ billion ( 1 million tons) to either $\$ 2.125$ billion or 2.550 billion (for 850,000 tons). Formulae would have to be negotiated to apportion the new level of accruals. The higher the accruals over the original level of receipts, the easier it would be to negotiate these formulae, as there will be more cash for trading-off of interests and the attractions of sustaining the scheme become a strong imperative for member countries. It is relevant to bear in mind the sharpincreases in prices of non-fuel commodities experienced in 1972-73 (63 per cent) and the three-year increase of 1971-74 (159 per cent). The following tables are an attempt to present the bare elements of the first stage of a scheme for Export Earnings Entitlements. The nuances of a negotiated scheme require that a large number of other refinements be brought in to complete the picture. Export Earnings Entitlements cannot be apportioned either on the basis of pre-agreement volume quotas or on the volume quotas within an agreement, as done in these tables. However, they provide the two extremes within which earnings allocations are negotiated, and some idea of the balance of interests that must be struck quantifying the whole range of costs and benefits of production, export and consumption rationalization. The allocation of volume quotas by assigning the entire cutback in exports to traditional producers is an extreme case, certainly to do so in just one single year. Equally extreme is the type of earnings share allocations considered. Other formulae must be designed with much greater flexibility. Export earnings are considered as the most vital objective and it is these earnings that are shared; but that does not preclude the possibility of assigning some quantified benefits for increased levels of consumption in the home market. This kind of adjustment is not considered in these tables, which merely set out one hypothetical situation, and an extreme one at that, at the stage of pre-negotiation, providing an idea of the raw basic data required by the negotiators. 
TABLE I

Pre-Agreement (Commodity X)

\begin{tabular}{cccccc} 
Countries & $\begin{array}{c}\text { Pre-Agreement (Commodity X) } \\
\text { Production } \\
\text { (tons) }\end{array}$ & $\begin{array}{c}\text { Exports } \\
\text { (tons) }\end{array}$ & $\begin{array}{c}\text { (\%) } \\
\text { Export earnings at } \\
(\$ 2.000 \text { per ton) } \\
\text { US \$ mn. }\end{array}$ & $(\%)$ \\
\hline A & 500.000 & 300.000 & 30 & 600 & 30 \\
B & 400.000 & 300.000 & 30 & 600 & 30 \\
C & 125.000 & 50.000 & 5 & 100 & 5 \\
D & 125.000 & 50.000 & 5 & 100 & 5 \\
E & 100.000 & 90.000 & 9 & 180 & 9 \\
F & 100.000 & 90.000 & 9 & 180 & 9 \\
G & 80.000 & 70.000 & 7 & 140 & 7 \\
H & 70.000 & 50.000 & 5 & 100 & 5 \\
\hline & 1.500 .000 & 1.000 .000 & $100 \%$ & 2.000 & $100 \%$ \\
\hline
\end{tabular}

TABLE II

Agreement Year

\begin{tabular}{cccccc} 
Countries & $\begin{array}{c}\text { Production } \\
\text { (tons) }\end{array}$ & $\begin{array}{c}\text { Exports } \\
\text { (tons) }\end{array}$ & $(\%)$ & $\begin{array}{c}\text { Export Earnings } \\
\text { at } \$ 2.500 \\
\text { per ton }\end{array}$ & $\begin{array}{c}\text { at } \$ 3.000 \\
\text { per ton }\end{array}$ \\
\hline A & 500.000 & 229.500 & 27 & 573.75 & 687.5 \\
B & 395.000 & 229.500 & 27 & 573.75 & 687.5 \\
C & 120.000 & 38.250 & 4.5 & 95.5 & 114.75 \\
D & 120.000 & 38.250 & 4.5 & 95.5 & 114.75 \\
E & 110.000 & 100.000 & 11.75 & 249.75 & 293.25 \\
F & 105.000 & 95.000 & 11.25 & 239.25 & 287.0 \\
G & 80.000 & 72.000 & 8.5 & 180.5 & 216.75 \\
H & 70.000 & 47.500 & 5.5 & 117.0 & 140.0 \\
\hline & 1.500 .000 & 850.000 & $100 \%$ & $2.125 \mathrm{M}$. & $2.550 \mathrm{M}$. \\
\hline
\end{tabular}

TABLE III

Agreement Year

Earnings Adjusted in Terms of Export Potential Shares

(Based for Convenience on Pre-Agreement Actual Export Shares)

Share of Adjusted

\begin{tabular}{cccc} 
Country & Export Earnings & at $\$ 2.500$ per ton & at $\$ 3.000$ per ton \\
A & 30 & 637.75 & 765.0 \\
B & 30 & 637.5 & 765.0 \\
C & 5 & 106.25 & 127.50 \\
D & 5 & 106.25 & 127.50 \\
E & 9 & 191.25 & 229.50 \\
F & 9 & 191.25 & 229.50 \\
G & 7 & 148.75 & 177.50 \\
H & 5 & 106.25 & 127.50 \\
\hline
\end{tabular}




\section{Explanatory Notes}

1. Countries A, B, C \& D are old, traditional producers with large domestic markets, and with production stabilized at present levels.

2. E, F, G \& H are producers with production expansion programmes.

3. The product is assumed to be homogeneous and market imperfections are ignored so that all countries receive the identical unit value.

4. An export volume quota of 850.000 tons is assumed, a cutback of export supplies by 15 per cent in table II.

5. Two possible price scenarious consequent on export restriction are noted - a 25 per cent and 50 per cent increase in unit prices.

6. Export earnings are worked out on the basis of receipts by each country in table I and II.

7. In table III, an initial allocation is worked out on the basis of EXPORT POTENTIAL defined as the share of earnings or export volumes in the pre-agreement year.

8. Countries A, B, C \& D take substantial cuts in their export volumes in the agreement year (table II).

9. Countries E, F \& G not only maintain but increase export volumes in agreement year due to expanded production. They export most of their output as domestic markets are absent (table II).

10. If export earnings shares are based on the export volume shares, countries A, B, C \& D lose earnings in relation to the pre-agreement year if earnings rise only 25 per cent with a cutback of 15 per cent of exports. They will make gains under the other two scenarios - (1) a 50 per cent price increase and division of export earnings based on export volumes, or (2) a 25 per cent or 50 per cent price increase and earnings divided or export potential as reflected in the level of export volume or export earnings shares in the pre-agreement year.

11. Countries E, F, G \& H make gains in every situation though export volume shares work in their favour.

12. No benefits are noted for the extra supplies diverted to the domestic market of the larger producers.

13. No costs are taken account of for the proportionately larger volumes exported by the expanding producers in the event of shares being allocated on the basis of export earnings.

\section{Institutional Mechanisms}

What are the types of institutions necessary to implement a commodity agreement on these lines? At this stage, only co-operation among producers will be envisaged, though the implementation of any agreements would be greatly facilitated if consumer countries were to co-operate, and indeed be party to a broader International Commodity Agreement encompassing the salient features of the Export Earnings Entitlement Scheme.

A centralized institution to handle the trade of an individual commodity produced by several countries is not only unnecessary but might also be impractical. An agency to monitor the provisions of the Agreement, to undertake a clearing-house function in relation to information and statistics, and an accounting function will indeed be necessary. It will be broadly similar to and not larger than any one of the commodity agencies so far established within the orbit of International Commodity Agreements.

Its more important tasks would be: - 
(1) Ascertain price trends in the commodity concerned and advise members to regulate supplies to the market within the ceiling set for the relevant period. It will be its task by such means to engineer the unit price of the commodity to be maintained at levels consistent with the global revenue figure.

(2) At the end of the relevant period, it would facilitate the clearing of revenue acccruals in order that each member country obtains its proper share of total revenue as set forth in the Agreement. No member country should obtain more than its proper share and no member country less. Reconciliation of accounts will have to be undertaken at frequent intervals. (3) Service inter-governmental meetings to monitor the implementation of the Agreement, to renew the Agreement from time to time and to modify any of its provisions.

(4) Undertake the administration of any General or Specialized Fund set up under the Agreement. Funds for diversification, promotion, and research and development might be appropriately established.

\section{Export Earnings Entitlement (EEES) - Its Rationale}

The central feature of the proposed scheme is to focus the attention of the producer countries on the total level of export earnings from a commodity. If supply could be regulated, the commodity would be transacted in a seller's market, unit prices would rise and total export earnings accordingly. A major obstacle to the achievement of tight supply conditions is the failure among producing countries to agree on a firm global export quota, though they are fairly clear at most times on the level at which a ceiling should be placed on supplies, and also on the desirable unit price. The dilemma of an individual country arises out of the techniques deployed for regulation of exports. While producing countries agree on a global quota, a major conflict of interests is evident in the allocation of individual country quotas. As export earnings are dependent on the volume of exports, each country negotiates for the maximum exportable quota. Failure to reach agreement or agreement reached at the cost of a firm global quota which might have ensured tight supply conditions is the end result. The conflict between the desirable level of a global volume of exports and individual country export volume quotas have denied producing countries of the benefits they would derive from viable international commodity agreements. In this environment the consumer countries whose particular concern is access to supplies find it convenient to hold back, watching the unease which exists between old and new producers, and assisting new producers to expand capacity establishing in fact a mutual interest not among producing countries, but between new producers in an expansionary phase and consuming countries which have not only the markets and the trading expertise, but also the foreign capital for investment in new capacity. Tensions between producing countries have therefore been aggravated and producer co-operation substantially restricted in scope.

It has been noted that producer countries tend to agree on the need to limit global supplies. In that event, mechanisms must be sought to achieve that objective, while at the same time ensuring that the benefits accruing to the commodity from tight supply conditions is shared equitably among exporting countries. Export volume quotas and production controls create more problems than they solve, and should therefore be relegated as control mechanisms. The higher the individual claims for export volume quotas, the higher the global quota and the end result is a contradiction in terms, with enough dissatisfaction to rénege on the agreement at the earliest opportunity. The major problem among exporting countriess regarding the allocation of incremental benefits incidental on commodity agreements could be resolved 
if the focus of negotiations becomes the allocation of export earnings, in contrast to export volumes. The haggle should not be on the export volume. The allocation of export volumes and export earnings of an individual country need not necessarily be linked. What is proposed is to look at the volume of exports only in relation to a global export volume which ensures reasonable unit prices and aggregate earnings and find another measure - in this case, the most liquid of measures, cash - to allocate the share of export proceeds taking account of all relevant factors which provide the relative strength of each producing/exporting country in an individual commodity market. Once the costs and sacrifices of an individual producing country are compensated for in cash, it will indeed be realized that foregoing export volumes is no cost or sacrifice at all.

The clamour for a greater share in volume terms has helped only the consumer countries and has caused the secular decline in the terms of trade of primary commodities. The actual physical level of exports in volume terms need not be the yardstick of the relative strength of a country exporting a commodity. The strength lies in its potential for exports; in the short run, excess export capacity and in the medium and long run other comparative advantages which enable a country to bring new production into stream. It is these factors that could be taken into account in the allocation of export earnings de-linked from actual volumes exported.

A primary rationale of the scheme is to shift the burden of the costs of restructuring the commodity market away from producing countries. The structures of production of commodity markets have changed and are changing and the costs assiciated with these changes have been borne entirely by producing countries. The consumers have not only benefited by unreasonably low prices consequent on excess supplies, but also profited by new investment in countries entering into an expansionary production phase. A buyer's market has also deterred producer countries from venturing into downstream marketing and distribution operations, and by restricting resources available to the commodity, has held down the level of funds available for $\mathrm{R}$ and $\mathrm{D}$ and for promotion. New dependencies are created by making available funds for the commodity sector on strict conditionality. It is important that the commodity sector in producing countries achieves a degree of self-reliance in the generation of its own resources for deepening its own capital structure. The feasibility of operating Export Entitlement Schemes will be considerably enhanced if significant improvements in prices could be effected through such a scheme. The inelastic demand patterns for most primary commodities make such a result likely. This, however, does not mean an attempt to expropriate unreasonable prices from consumers. Price projections for commodities and other forecasts indicate a gradual but substantial erosion of real prices for several commodities, notably agricultural commodities of export interest to developing countries. If the scheme is tailored to halt this trend (after an initial and rapid adjustment of prices to make up for the substantial real losses incurred in recent years) the developing and developed countries should find in schemes of this nature a practical basis for negotiation of a more predictable international commodity economy.

\section{Constraints}

Co-operation among producing countries, even of a single commodity, bristles with difficulties. The management of the mutual interests which undeniably exist within such a group require both great skills of diplomacy and a perception of the advantages which would accrue and outweigh the elements of competition and conflict among them. Within existing 
systems and proposals, the mutual interest is not so much among producing countries and such perceptions of mutuality of interest are strongly buttressed by powerful financial and economic interests at a national and international level. A realistic appraisal of the potential for producer co-operation must note these realities and evolve proposals which overcome these manifold obstacles. A primary objective of an Export Earnings Entitlement Scheme is to take account of these factors; there is sufficient flexibility for the negotiaton to design a scheme in which costs and benefits could be precisely balanced so that a balance of interests is achieved among the members of the group, while at the same time ensuring incremental gains for each and every member.

An element of political goodwill among participating countries is a necessary pre-condition for the success of any scheme of producer co-operation. This should be forthcoming in large measure when there is a convergence of economic interest irrespective of the differences in political systems, as is evident in several other situations. An Export Earnings Entitlement Scheme - if it is to minimize the complexity of central bureaucracies for administrative purposes - must rely on the good offices of governments to monitor the implementation of the scheme and to transfer funds from time to time between them, depending on the surpluses and shortfalls generated by each country in relation to share allocation within the scheme. Co-operation among the central banks of participating countries could be a subsidiary gain from a scheme of this nature.

The unit price of the product under the scheme accruing to each country could be different depending on the manner in which quotas are allocated. If the advantage of large domestic markets in producing countries is to be fully exploited and the disposal of surpluses minimized, specifically in agricultural commodities, some differences in unit values would result. Lower unit values would probably accrue to the low cost producers but that is the price to be paid for more generous quotas in their case, which is a particular demand of new producers. Even here adjustments are possible to take account of the costs and gains to each country and their quantification should be relatively easy. In the case of minerals, where the maintenance of excess idle capacity is feasible, this problem should not arise.

It is an assumption of the scheme, though not a necessary one, that countries will not be particularly concerned with the maximization of their export volume quotas as export earnings are allocated primarily on the criteria of export potential rather than national export volumes. The countries who might be anxious in the initial stages for maximum quotas are the new producers and it is a particular attraction of this scheme that it is possible to accede to their needs. However, the old producers, in the absence of domestic markets or by a desire to maintain their traditional market outlets and buyers' preferences on to maintain their future bargaining postition, might desire to maintain a volume share larger than visualized here. If that happens, quotas elsewhere will have to be reduced, though accommodation will be relatively easy once this factor is not intimately linked to allocation of export earnings.

During the initial share allocation, previous export volume shares were a relevant consideration. Will this still be a relevant criterion in the event of re-negotiation? If so, countries would not opt to give up any part of their export volume shares. It is important to stress that the relevant criterion is not actual export volumes but the export potential. Initially, actual export volumes are relevant as prior to an agreement such volumes are a reflection of the export potential. Subsequently, it is not actual export volumes that must be considered, but the export potential.

This, however, raises another issue - the issue of production control. Production controls will only be undertaken in those commodities where idle excess capacity could be maintained and switched back to production if the Agreement fails. In the case of agricultural com- 
modities, this will be difficult and it will not be possible to anticipate cutbacks in production in the short-term. Countries will go on producing, but there will be an incentive for those with large home markets to switch part of the exports to domestic consumption if the future negotiating criterion is export potential and not actual export volume. In the case of new and expanding producers, cutbacks in production will have to wait for sometime. The higher export earnings accruing to them as a result of the Agreement should make them realize that expansion of output does not give them additional earning capacity in the event of the Agreement being terminated. In the case of agricultural land, there is also the opportunity cost involved. If the Agreement establishing the scheme incorporates within it a Diversification Fund which offers development finance on attractive terms to further the objectives of the agreement, it would certainly be possible to effect, in the medium term, the required degree of production control.

\section{Indexation and Compensatory Finance Schemes}

The Export Earnings Entitlement Scheme builds into it automatically two major elements which are currently the subjects of international discussion: Indexation and Compensatory Finance. If the total size of earnings from a commodity are set at reasonable levels on the basis of the criteria referred to above, indexation would ensue assuring the producer some proof against inflation and ensuring the maintenance of a satisfactory price in real terms. An attraction of the scheme is the feasibility of indexing prices either in real terms or in relation to the import capacity of the commodity exporting countries. A substantial number of commodity exporting countries are importers of food, particularly cereals like wheat and rice. This, and several other reasons make the indexation of primary commodity prices in relation to the price of wheat an attractive proposition.

The increasing recognition of the imperative need for Compensatory Finance to ensure reasonable levels of resource flows to commodity exporting countries provides a rationale for the Export Earnings Entitlement Scheme which could be operated even unilaterally by producer countries and which has the same basic objectives. A major difference between Compensatory Finance Schemes and the EEES is that, while the former is an aid scheme with probably conditionality imposed on the recipient, the latter will be an exercise in market intervention to obtain a fair and remunerative price for producer countries.

\section{Implications for the Common Fund}

The proposed scheme has substantial implications for the operation of the Common Fund. The Common Fund assumes signifiance to the extent that individual commodity agreements are negotiated and the problem so far has been the inability to conclude commodity agreements primarily due to the weak bargaining strength of producing countries. It is expected that the proposals set forth here if adopted might strengthen the position of producer countries and encourage consumers to come to the negotiating table with firm commitments in the form of reasonable and remunerative floor prices for commodities, equitable burden sharing in commodity stocking to even out price fluctuations, and provisions for market access to processed products.

If prices are raised under the provisions of Export Earnings Entitlements Schemes, the consumers will have a major interest in both buffer stocks and levels of ceiling prices. The pro- 
ducing countries too will find it in their interest to resort to short-term stocking to avoid any sharp increases in prices. Provided the floor price is sufficiently high, stocks could be accumulated at times, and a narrow price band between floor and ceiling prices might result in great buoyancy in the management of buffer stocks. The Common Fund will find its true rationale in this context, and its attractions to the consuming countries would probably outweigh its advantages to the producers. In the interests of consumer co-operation in Export Earnings Entitlements Schemes, the producing countries when fixing its global export volume might take into account the need to allow for a small stock to be financed by the Common Fund particularly at times of seasonal glut. A stock of this nature will also assist even marginally to resolve the question of the surpluss supply, though an internationally managed buffer stock should not be relied on exclusively, with the corresponding fear of a market overhang.

\section{Excess Supplies}

Every commodity agreement which aims to restrict the supplies to the market must invariably confront the problem of the excess supply. Ultimately, the solution is production control but considerable constraints exist for such measures to be adopted in the short and medium term. It is clear from the description of the EEES that the first attempt to get rid of excess supplies must be through a process of rationalization of consumption patterns within the producing countries. In their search for foreign exchange, producing countries have denied their domestic markets and domestic prices maintained at levels higher than they could have been.

The domestic market is a kind of residual market when in fact it might pay the country concerned to be restrictive on exports. The problem of excess supply and its incidence would vary among commodities. In the case of agricultural commodities, particularly in tree crops (where, unlike wheat or maize or rice, the land cannot be allowed to lie fallow), there will be a physical excess which then has either to be consumed locally or destroyed or sold in some residual market which is not usually a consumer. Stocks are not a suitable remedy beyond a certain level as they create the dangers of a market overhang. It is possible in the case of these commodities to absorb most of the surplus through local consumption and residual, closed markets. It is also possible to reduce production not by reducing capacity, but by more selective methods of cropping and accelerated replanting schemes. In the case of minerals, the shift to spare capacity will probably be the most feasible.

Limitations on the level of exports and disposal of the consequent surplus have implications for the pattern of export income distribution within each country and intervention on the part of governments will be necessary. However, such market intervention is commonly practised even in the developed countries, and the Common Agricultural Policy of the EEC with its complex system of levies and subsidies need not be repeated. A much simpler apparatus is all that is required. A Common Commodity Policy incorporating the salient features of both export and subsistence production must emerge gradually both at a country level and among commodity producing developing countries. 


\section{Special Characteristics of Agricultural Commodities}

One of the neglected aspects of international trade in commodities originating in the developing countries, is the significance to such trade of the growing scarcity of arable land. This was not a significant element a decade ago, and is relevant only to agricultural commodities, particularly to those which under most circumstances cannot be either produced in, or substituted for, in the rich, industrialized countries. Natural rubber, tea, coffee and cocoa fit these criteria and even the other commodities to a lesser extent are not fully substitutable in the context of both a scarcity of land and high costs of energy. Just like the other factors of production - capital and technology and energy - the command over this unique resource of land ideally suitable for these crops - should enable producer countries to obtain an economic rent for their use which is demanded by the other three factors of production referred to.

An analysis of the cost of production data of these commodities reveals major under-estimates of the costs incurred by the producer countries in cultivating land for export crops. The imputed value of land in calculating costs of production is surprisingly small and the opportunity and environmental costs must be examined more carefully in arriving at costs of production relevant to international negotiations. The foreign currency component in the cost structure should be properly assessed taking due note of local subsidies of input and tax concessions.

The production of commodities for export, in general, and more particularly agricultural commodities involve significant expenditures of foreign currency for producing, developing countries. Efficiency of their operations is maintained at present levels by increasing expenditures of foreign currency and the foreign currency component in the unit cost of production has increased significantly in recent years. The cost of energy, directly used in processing, whether it be oil or firewood (firewood being a direct substitute for oil and with a heavy opportunity cost in terms of its non-use by the indigenous population for which it is the primary source of energy), fertilizers, transport equipment, packing material, and other indirect foreign costs, e. g., the foreign cost component in labour wages are substantial cost elements both for the individual commodity and the country as reflected in the balance of payments, that it is feasible to effect reductions in these costs by lower levels of production.

An attractive subsidiary effect of an Export Earnings Entitlement Scheme will be the reduction in foreign currency expenditures in the production of commodities for export.

Any restriction of exports of an agricultural commodity while ensuring either the same or increasing levels of global export incomes, releases a not insubstantial extent of land to be devoted either to other crops - for local food consumption or even more exotic export crops or for local consumption of the same commodity generating welfare gains. Tea is a neat illustration where domestic consumption is curbed to ensure supplies for export. The land that would be released would have a highly developed infrastructure and is not comparable with undeveloped land which requires large costs, to be brought into production. 
The Relationship between the Social-Structure and the Working of the Legal System: A Case Study on Access to Justice in Northern Nigeria

By M. L. MARASINGHE

The paper is intended to support the thesis that there exists a relationship between the social infra-structure of a given society and the workings of the legal system which presides over it. In an attempt to examine this relationship a Tribal legal system in the province of Katsina, in Northern Nigeria was chosen. Out of empirical research conducted in the Native or Tribal Courts in that region, a mass of 1500 decisions were collected and translated into English for use in this and other similar writings. Of this mass of 1500 cases, 300 cases have been chosen for use in this paper. These cases have been categorised into two broad categories. First, those concerned with the 'Customary' oaths and the second concerned with Divorce proceedings. These two areas have been singled out for the purposes of this paper for the reason that they both manifest strong cultural underpinnings peculiar to the societies to which they belong. The purpose of the paper is to show the extent to which the infra-structure of a given Tribal society and the workings of the legal system presiding over it maintains a distinct harmony, so that the social and/or Tribal manifestations are reflected to a very large measure in the decisions produced by the Native or Tribals Courts functioning in that society. At the concluding stages of this paper it is intended to show the extent to which the decisions made by the Nigerian Courts adjudicating outside the system of Native Law and Custom departs from the social and cultural underpinnings of the Native or Tribal societies in Nigeria.

\section{International Commodity Trade:}

A Scheme for Export Earnings Entitlements

By Leelananda De Silva

The stock ingredients of international commodity agreements - export quotas, production controls and buffer stocks - have not been effective instruments in supply management as they fail to exploit adequately the mutual interests which exist among commodity producing/exporting countries. The mutual interest of producing/exporting countries lies in the expansion of export earnings both for the commodity as a whole and for each individual country and a scheme to share these earnings through Export Earnings Entitlements could prove more flexible, realistic and effective. Export volume quotas, production controls and buffer stocks would be ancillary and supporting measures to achieve the primary objective of export earnings allocations. The central element of the scheme is to de-link, at least partially the present direct relationship between each country's volume of exports and its export earnings. An Export Earnings Entitlement Scheme should allocate earnings to each country not necessarily on the actual volumes it exports but on its Export Potential taking due regard of the principle that in an international commodity agreement both exports an the withholding of exports in the interests of supply management are contrubutions to the expansion of total export earnings. By concentrating attention on the distribution and allocation of cash rather than on quantities of commodities (export volumes quotas), it might be feasible by allocations of less or more cash to balance the costs and benefits accruing to each producing/exporting country within a commodity agreement. Imaginative formulation and operation of an Export Earnings Entitlement scheme might in time assist in the emergence of a 
rationalized production and consumption structure for a commodity, without the costs of rationalization being borne by producing/exporting countries which are least able to bear these costs.

\section{Administrative Reform and Urban Development:}

The Case of Manila

\section{By JURGEN RULAND}

Rapid urbanization in Metropolitan Manila causes multiple problems in planning, coordination and provision of services. It has been intended to tackle these problems through the reorganization of the local government system into a centralized metrowide commissiontype of government (Metro Manila Commission) in 1975. The restriction of autonomy of the 17 local units, comprising the Metropolitan Manila Area, was expected to result in more comprehensive planning, more rational distribution of public resources and a greater output of public services - thus, transforming Metro Manila from a "dying city" into a "City of Man". This article evaluates the success of this program.

The first section is devoted to the organizational changes which occured since 1975. Thereafter those factors which primarily determine the service output will be investigated, namely, the way in which the public officials see development and the process of planning. These officials perceive development exclusively in terms of western development strategies. It is argued, however, that these strategies do not fit to the Manila setting, since they are not able to integrate the traditional and informal sectors. The ill considered adoption of 'modern' technocratic strategies of development promotes a further impoverishment of these sectors constituting the majority of the urban population. Both, before and after 1975, planning and project implementation has been retarded by numerous deficiencies and bottlenecks.

The third section deals with some key services (tax administration, finance, land use, housing and infrastructure). Major finding is that only a minority, 20-30\% of upper and upper middle class Manilans and the 'modern' sector coinciding with the major domestic and foreign business interests, benefits from the improvement of services.

Consequently the 1975 administrative reforms in Metro Manila must be considered a failure. Most of the administrative problems indentified as contributing to the deterioration of living conditions in Metro Manila, still persist. It is hypothesized that the failure of the administrative reforms is due to political considerations of regime stabilization which dominate the service functions of the administration. The politically most sensitive area of the Philippines is now controlled by the regime through the domination of the decision-making processes and the implementation of decisions. Before 1972, the 17 local units in Metro Manila were highly policized bases of the political opposition with relatively autonomus local governments. Metro Manila is the center of the Philippine economy concentrating the bulk of financial institutions, big business companies, investments, both, of the ruling oligarchy and foreign. Therefore, the reorganization of the metropolitan government along centralized lines has to be seen as one of a series of steps (1973 Constitution, suspension of the legislatives, formal disbanding of political parties, various rigged referenda and elections as a basis of legitimation, a muzzled mass media and a controlled judiciary) aiming at the consolidation of the Marcos' Martial Law regime. 